\title{
The Effect of Service Quality and Product Diversity on Customer Loyalty: The Role of Customer Satisfaction and Word of Mouth*
}

\author{
Endang TJAHJANINGSIH ${ }^{1}$, Dewi Handayani Untari NINGSIH ${ }^{2}$, Agus Prasetyo UTOMO
}

Received: September 01, 2020 Revised: October 26, 2020 Accepted: November 05, 2020

\begin{abstract}
Batik industry is a business activity oriented towards customer loyalty and is demanded to show an increasing diversity of products with various motives designed to prevent customers from moving to other companies. Therefore, the purpose of this study is to develop a theoretical approach in solving problems in the relationship between service quality and product diversity on satisfaction and word of mouth (WoM) and its impact on customer loyalty. Furthermore, this study also examined the mediating effects of satisfaction and WoM in the relationship between service quality and product diversity on customer loyalty. This research's object took the customers of Batik Semarangan Craftwork, Indonesia, with the phenomenon of always developing creative and innovative Batik motif designs that can be accepted by the market without leaving Semarang's uniqueness. The total sample was 98 customers. The results of the study showed that service quality and product diversity positively affected satisfaction and WoM and had a positive effect on customer loyalty. Besides, satisfaction and WoM had a mediating effect on the effect of service quality and product diversity on loyalty. Thus, it is essential for management to create and increase customer loyalty by paying attention to service quality, product diversity, satisfaction, and WoM.
\end{abstract}

Keywords: Service Quality, Product Diversity, Satisfaction, Word of Mouth, Loyalty

JEL Classification Code: J28, M31, O14, P42

\section{Introduction}

The existence, development, and advancement of efforts to survive in a competitive market are related to the company's strategy to adapt to customers' ever-changing needs. The batik industry is a business activity oriented towards customer loyalty and there is a growing demand from the inductry to show an increasing diversity of products with various motives designed to prevent customers from

\footnotetext{
*Acknowledgements:

The authors would like to thank The Directorate General of Higher Education, Indonesia, for research funding with the scheme of Stranas Institution 2020.

${ }^{1}$ First Author and Corresponding Author. Faculty of Economics and Business, Stikubank University, Semarang, Indonesia [Postal Address: Jl. Kendeng V, Bendan Ngisor, Kec. Semarang Sel., Kota Semarang, Jawa Tengah 50241, Indonesia] Email: e.cahaya22@gmail.com

${ }^{2}$ Faculty of Technology and Informatics, Stikubank University, Semarang, Indonesia

${ }^{3}$ Faculty of Technology and Informatics, Stikubank University, Semarang, Indonesia

(c) Copyright: The Author(s)

This is an Open Access article distributed under the terms of the Creative Commons Attribution Non-Commercial License (https://creativecommons.org/licenses/by-nc/4.0/) which permits unrestricted non-commercial use, distribution, and reproduction in any medium, provided the original work is properly cited.
}

moving to other companies. It is a challenge for the batik industry to retain customers amid intense competition by making various efforts to improve service quality and the product diversity to increase satisfaction and good word of mouth to build customer loyalty.

Seeing this fact, the batik industry must be able to maintain its potential to improve marketing strategies further, considering the many competitors of Batik Semarangan. Semarangan batik is, on an average, a product of batik MSMEs that is growing very slowly. Until now, the position of Semarangan batik was still at an embryonic level. Based on research conducted by Tjahjaningsih et al. (2017) and the real conditions on the field, it showed that Semarang people and the broader community did not know well about the typical Semarangan batik motifs. In fact, batik products are produced based on market trends and public interest without eliminating cultural roots to keep up with the times by providing good quality service and product diversity. In line with the rapid development and business competition, companies are required to develop their products continuously by providing good quality services to ensure their business's survival.

The batik craftwork business unit is a business unit formed from the results of the research output of the Master Plan for the Acceleration of Indonesian Development (Tjahjaningsih 
et al., 2016), whose activities are currently developing as a business that produces batik both in the form of fabrics and fashion as well as developing various derivative craft products using natural dyes. Batik craftwork is a form of community-based business whose primary objective is to empower the community and utilize surrounding natural resources, developing batik motifs with a philosophy. Batik craftwork is also at the center of research and development of various innovative processes and products implemented in the mass production of written and printed batik.

One of the several efforts to develop creative and innovative work is the Semarangan batik motif design that is acceptable to the market without leaving Semarang's uniqueness (Tjahjaningsih et al., 2020). The use of computer-assisted designs using fractal, Photoshop, and CorelDraw concept software, which can combine drawing techniques with effects or electronic brushes, can speed up motifs' creation that is then reproduced for further processing in batik.

Computer-assisted motif designs utilize fractal software to speed up the process and develop various motifs based on library objects stored in the fractal batik library to be developed into a variety of different motifs (Figure 1). Using the L-System algorithm and mathematical formula, batik motifs can be made easily via a computer in a relatively faster time and are easy to reproduce. How to design computerassisted batik using the fractal method has been developed, but in combination with other software to minimize the design's monotony. Several patterns are needed to form the overall batik motif so that the batik becomes a unique work, which is not only suitable for clothing but can also be used as a garment that exudes its owner's uniqueness. From this peculiarity, it is hoped that it can become a special characteristic and is difficult for the competitors to imitate due to the products' uniqueness. Batik craftwork develops various motifs produced from computer designs assisted by fractal software, becoming the hallmark of Semarangan batik with various derivative products according to market trends without leaving cultural elements. The Figure 1 is one of the batik craftwork products with natural dyes.

The various products made by the company reflect the company's ability to develop its business. Product diversity results from heterogeneity in demand from various consumer groups in the scenario of an intense competition, thus giving consumers many choices (Rokonuzzaman et al., 2020). Sari and Setiyowati (2017) and Suhaily and Soelasih's (2017) research explained that product diversity affected consumer satisfaction. Meanwhile, Wilujeng and Mudzakkir (2015) suggested that the product diversity had no significant effect on satisfaction. Besides, Bhattacharya and Sen (2003) carried out the research by giving the idea that customers with deep involvement in a company and its various products become supporters of the product or the company.

Moreover, perceived quality is the consumer's overall assessment of consumers' standard service process (Ranjbarian et al., 2012). According to the results of research by Coker (2013), Giovanis, Zondiros and Tomaras (2014), Shi, Prentice and He (2014), and Suhaily and Soelasih (2017), service quality affected satisfaction. However, the research by Hermawan et al. (2017) and Adi et al. (2019) disclosed that service quality did not affect satisfaction. Further, Shi, Prentice and He (2014), and Agha Kasiri et al. (2017) explained that service quality influenced loyalty. However, according to Jahanshahi et al. (2011), Muafa et al. (2020), and Solimun \& Fernades (2018), service quality had no impact on loyalty.

Certainly, building service quality and product diversity would increase satisfaction and word of mouth (WoM), as explained by Alrwashdeh, Jahmani and Blend (2020) that perceived telecommunication service quality and perceived value increased user satisfaction and e-WoM in the context of mobile operators in North Cyprus. WoM occurs when customers talk their opinions to others about a particular brand, product, service, or a company (Tsai et al., 2017). Besides, WoM strategy of using online social networking is generally believed to be effective for users because it makes a good place for word of mouth marketing ( $\mathrm{Li} \& \mathrm{Du}, 2017)$. If customers share their opinion about a product's goodness, it is called positive WoM; however, if customers spread their opinion about a product's badness, it is called negative WoM (Brown et al., 2005). Yoo, Sanders, Moon (2013) revealed that eWoM had an effect on e-loyalty in eCommerce. The research's results by Pauwels, Aksehirli, and Lackman (2016) also found that WoM marketing about product brands, advertisements, and purchases could drive online and offline sales.
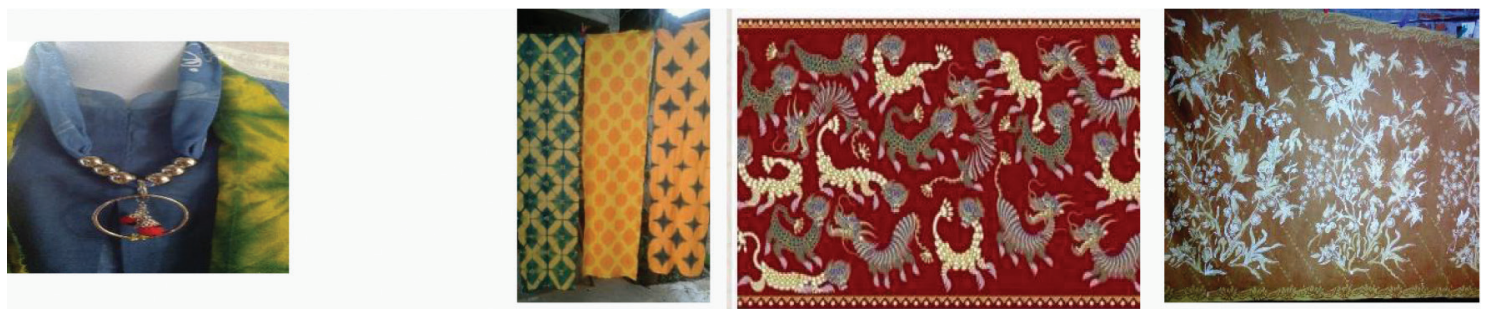

Figure 1: Batik with Creative Techniques 
Furthermore, customer satisfaction is customer feedback in the form of evaluation after purchasing some goods or services compared to customer expectations. Satisfied customers mean similarity between goods and services' performance with customer expectations, encouraging them to repurchase the product/service. At the same time, a disappointed customer will persuade other customers not to repurchase, and as a result, the customer will move to another brand's competitor (Razak et al., 2016). Besides, Kasiri et al. (2017) and Song, Wang, and Han (2019) uncovered that satisfaction influenced loyalty. In contrast, Powers and Choi (2018) revealed that satisfaction did not impact loyalty.

These phenomena are the background for the need for research aimed at analyzing how service quality and product diversity affect satisfaction and WoM, as well as their impact on loyalty, the mediating effect of satisfaction, and WoM on the effect of service quality and product diversity on loyalty.

\section{Hypotheses Development}

\subsection{Effect of Service Quality on Satisfaction}

Kotler and Keller (2012) define service quality as the totality of a product or service's features and characteristics that depends on its ability to satisfy stated or implied needs. Perceived service quality results from a consumer's evaluation of the service provider's overall excellence or superiority (Parasuraman, Zeithaml, \& Berry, 1988), usually measured by the SERVQUAL instrument (Parasuraman, Zeithaml, \& Berry, 1985). In order to achieve satisfactory service quality, five main dimensions of service quality must be considered: physical evidence, reliability, responsiveness, empathy, and assurance. Service quality is a crucial thing that must be considered and maximized in its implementation to continue to survive and always be customers' choice. The higher the service quality's performance compared to consumer expectations, the higher the customer satisfaction. According to the research of Alam \& Al-Amri (2020), Nguyen, Pham, Tran, \& Pham (2020), Shi, Prentice, \& He (2014), Lee \& Seong (2020), Suhaily \& Soelasih (2017), Tran \& Le (2020) that service quality affect customer satisfaction. Thus,

H1: Service quality has a positive effect on customer satisfaction.

\subsection{Effect of Product Diversity on Satisfaction}

Shorter product life cycles and increased competition in a competitive environment increase company uncertainty and organizations' need to adapt. Consequently, the company places the company's facilities designed/shaped to be flexible by being responsible for product lines and production processes. Product diversity makes up the choice of an item becoming increasingly varied; if the company is unable to provide heterogeneity in the consumer demand, it causes consumers to be less satisfied and less loyal to certain sellers (Rokonuzzaman, 2020). The company's flexibility leads to the ability to produce a wide range of products. Product diversity is an additional product of a core product, which can add value to the core product. Product diversity is an attraction for consumers, primarily as it can provide more varied alternative choices, which leads to consumer satisfaction. The higher the product diversity, the higher will be the customer satisfaction. According to the research of Utama and Ngatno (2017), Sari and Setiyowati (2017), and Febriana et al. (2017), product diversity influenced consumer satisfaction. Thus,

H2: Product diversity has a positive effect on customer satisfaction.

\subsection{Effect of Service Quality on WoM}

Word of Mouth (WoM) is the oldest mechanism through which it can be disseminated, expressed, and built regarding one's opinion on products, brands, and services (Cengiz \& Yayla, 2007). WoM is an exchange of information between people who know each other, either directly or indirectly. Besides, it is a communication from one person to another, where someone, as the information recipient, does not feel any commercial value when the information provider recommends things related to specific brands, products, or services. Otherwise, dissatisfied consumers will share unsatisfactory experiences and affect the impression about the product. Research results by Saktiani (2015) and Liu \& Lee (2016) disclosed that service quality positively affected WoM. The better the service quality, the more consumers have a pleasant experience, and this will be responded to by telling others both online and offline, and vice versa. If consumers have an unpleasant experience, it will be told to others. The higher the service quality, the higher the positive WoM. This leads to the following hypotheses:

\section{H3: Service quality has a positive effect on WoM.}

\subsection{Effect of Product Diversity on WoM}

Product diversity is more likely to be carried out by firms than non-diversity when they have difficulties related to R\&D activities (Tang, Tang, \& Su, 2019). When a company wants to find local applications for new knowledge, each R\&D unit must understand the wide range of technological expertise that the subsidiary has. Product diversity, as a product range that produces products with rapid changes in shape/design, follows consumers' needs and desires in accordance with prevailing trends, introduces products faster with diverse products, reduces uncertainty due to changes in consumer tastes, and increases competitiveness. Libai et al. (2010) found that encouraging customer-to-customer interactions could increase profitability. 
Compared to the traditional marketing activities, WoM referrals had a greater short-term response and a more prolonged carryover effect (Pauwels, 2009). Study results by Huda and Syahrul (2016), Adi, et al. (2019), and Anggraeni, Retnoningsih and Muhaimin (2019) revealed that product diversity had a positive impact on WoM. The higher the product diversity, the higher the positive WoM. Thus,

\section{H4: Product diversity positively affects WoM.}

\subsection{Effect of Service Quality on Customer Loyalty}

Griffin (2013) stated that customer loyalty is a positive attitude shown by customers towards a product/service provider by repurchasing products or services offered by the company in the long term and recommending the company to colleagues and their families. The better the service quality, the better the current customer commitment to deal with a particular seller, brand, or service provider, although there are other alternatives that the customers can choose from (Shankar et al. 2003). It showed higher customers' positive attitude in the form of repeated purchasing behavior from time to time. The results of research by Setyowati \& Wiyadi (2016), Susanti \& Ekazaputri (2018), and Adi et al. (2019) discovered that service quality positively impacted consumer loyalty. The higher the service quality, the higher the customer loyalty. This leads to the following hypotheses:

H5: Service quality has a positive effect on customer loyalty.

\subsection{Effect of Product Diversity on Customer Loyalty}

The ultimate goals in achieving customer loyalty are to increase sales revenue through increased purchase or use, increase the diversity of products purchased, and retain existing customers by fostering close relationships between the product or service providers and current customers (Hammond et al., 2013). Product diversity is product creativity and process innovation that can explain the excellence orientation of specific creative techniques that have the advantages of product development, product differentiation, and cost-oriented creative processes. Loyal product users are often the target of various products, choices that make them want to try products repeatedly. The results of research by Prasetyo (2007), Nurhasanah (2010), and Nuraini (2014) explained that product diversity had a positive effect on customer loyalty. The higher the product diversity, the higher customer loyalty. This leads to the following hypotheses:

H6: Product diversity has a positive effect on customer loyalty.

\subsection{The Effect of WoM on Customer Loyalty}

WoM refers to the efforts made by people who have purchased a product, potential consumers, and actual consumers to highlight both the positive and negative attributes of a product or a company. WoM persuasion will drive product purchases, depending on the WoM content. In particular, WoM contains product reviews and purchases that will positively affect a product's purchase compared to WoM that only contains product details (Tsai et al., 2017). Liang \& Scammon (2011) suggested that reading online recommendations would influence online purchase intentions. Also, online recommendation sources can be a traditional recommendation source or an upcoming recommendation system within a group. Information about the site and its offerings will provide assurance for consumers. Findings of Dennis et al. (2009), Liang and Scammon (2011), and Yoo, Sanders, Moon (2013) explained that WoM positively affected customer loyalty. The higher the WoM, the higher the customer loyalty. Thus,

\section{H7: WoM has a positive effect on customer loyalty}

\subsection{Effect of Satisfaction on Customer Loyalty}

Jahanshahi et al. (2011) stated that customer satisfaction results from customer perceptions of the value received in a transaction or relationship where value complements the service quality perceived by the customers relative to the price and the cost. Lombart and Louis (2012) showed that the result of customer satisfaction is customer loyalty. The higher the consumer satisfaction, the more the product performance is considered to be better as per the expectations of the customers and as a result customers are prone to talk about positive things about the product and the service as well as perform repeat purchase in future. Walter, Cle ff, Chu (2013), Adi et al. (2019), and Hak, Wang, and Han (2019) stated that consumer satisfaction positively influenced consumer loyalty. Customers who feel that they get the product's performance or service according to their expectations will be consistent and have a high commitment in the form of loyalty. Thus,

H8: Satisfaction has a positive effect on customer loyalty.

\section{Research Methods}

In this study, primary data were obtained directly from respondents through questions/questionnaires by the respondents. The population was all customers of Batik Semarangan Craftwork. The sample size in this study was 96 customers. The sampling technique was purposive sampling with the criteria that consumers had purchased the batik craft 
product at least two times and were willing to provide the required information.

The data collection method used was a questionnaire method using a 1-7 Likert scale. The measurement scale of service quality variable was measured using 22 question items developed by Parasuraman (1988), and product diversity was calculated employing five-question items developed by Chang et al. (2012). Besides, satisfaction was determined using five-question items developed by Kotler and Keller (2012), WoM was assessed employing three-question items developed by Tsai et al. (2017), and loyalty was gauged using four-question items developed by Kotler and Keller (2012).

The data processing technique was carried out using descriptive analysis and statistical analysis. Descriptive analysis was used to determine respondents' general description, while statistical analysis was employed to answer research questions by analyzing and testing the empirical model with multiple regression and Sobel test using SPSS 22.0 software.

\section{Results}

Respondents in this study were Batik Semarangan Craftwork customers. The number of questionnaires distributed to respondents was 100 questionnaires, and after the research was carried out, 98 questionnaires were declared feasible so that they were designated as research samples for further processing. Based on the research results, it was known that respondents at the age of $40-49$ were 40 people $(40.8 \%$ ), female gender consisted of 66 people (67.34\%), having jobs as entrepreneurs were 30 people (30.61\%), and the latest education background of bachelor (S1) was $290(29.59 \%)$ respondents.

\subsection{Validity and Reliability Test}

Based on the calculation, the KMO (Kaiser-MeyerOlkin) value of each variable was higher than 0.5 , and Bartlett's Test of Sphericity (Sig.) value was $<0.05$. From these requirements, each variable met the factor analysis test criteria. All questionnaire items' loading factor value was higher than 0.5 so that all items were declared valid. The reliability test in this study utilized a Cronbach alpha value of 0.7 , where a measuring instrument was declared to be more reliable if the Cronbach alpha calculation results were above 0.7 . Likewise, in the variance extract test, no value was below 0.50 .

\subsection{Multiple Linear Regression Analysis}

Furthermore, testing the empirical model with multiple linear regression was performed in Table 1.

$$
\text { Regression equation I: } \mathrm{Y} 1=0.494 \mathrm{X} 1+0.326 \mathrm{X} 2
$$

The regression equation had a standardized coefficient value of 0.494 for service quality and 0.326 for product diversity. Service quality had a more substantial influence on customer satisfaction than product diversity; it was due to reliability, responsiveness, assurance, empathy, and evidence according to customer expectations in influencing customer satisfaction. Building customer satisfaction requires a high service quality.

Regression equation II: $\mathrm{Y} 2=0.601 \mathrm{X} 1+0.241 \mathrm{X} 2$

Table 1: Results of Multiple Linear Regression Analysis

\begin{tabular}{|c|c|c|c|c|c|c|}
\hline \multirow[b]{2}{*}{ Regression Model } & \multicolumn{3}{|c|}{ Model Test } & \multicolumn{2}{|c|}{$T$ test } & \multirow{2}{*}{ Information } \\
\hline & $\begin{array}{c}\text { Adj } R \\
\text { Square }\end{array}$ & F Count & Sig. & $\beta$ & Sig & \\
\hline $\mathrm{Y} 1=\alpha 1+\beta 1 \mathrm{X} 1+\beta 2 \mathrm{X} 2+\mathrm{e} 1$ & 0.502 & 50,948 & 0.000 & & & \\
\hline Quality of service to satisfaction & & & & 0.494 & 0.000 & $\mathrm{H} 1$ is accepted \\
\hline Product diversity on satisfaction & & & & 0.326 & 0.000 & $\mathrm{H} 2$ is accepted \\
\hline $\mathrm{Y} 2=\alpha 2+\beta 3 \mathrm{X} 1+\beta 4 \mathrm{X} 2+\mathrm{e} 2$ & 0.556 & 62,957 & 0.000 & & & \\
\hline Quality of service to WOM & & & & 0.601 & 0.000 & $\mathrm{H} 3$ is accepted \\
\hline Product diversity against WOM & & & & 0.241 & 0.002 & $\mathrm{H} 4$ is accepted \\
\hline $\begin{aligned} Y 3 & =\alpha 3+\beta 5 X 1+\beta 6 X 2+\beta 7 Y 1 \\
& +\beta 8 Y 8+e 3\end{aligned}$ & 0.714 & 62,639 & 62,639 & & & \\
\hline Quality of service to loyalty & & & & 0.217 & 0.009 & H5 is accepted \\
\hline Product diversity towards loyalty & & & & 0.135 & 0.048 & $\mathrm{H} 6$ is accepted \\
\hline WOM towards loyalty & & & & 0.246 & 0.008 & $\mathrm{H} 7$ is accepted \\
\hline Satisfaction with loyalty & & & & 0.364 & 0.000 & $\mathrm{H} 8$ is accepted \\
\hline
\end{tabular}


The regression equation had a standardized coefficient value of 0.601 for service quality and 0.241 for product diversity. Product diversity had a more substantial influence on customer WoM than service quality. It was due to various products, product coverage in the form of changes in shape, and design/motif according to the prevailing trend in accordance with customer expectations in influencing customer WoM. Building customer WoM requires high product diversity.

$$
\begin{aligned}
\text { Regression equation III: } \mathrm{Y} 3 & =0.217 \mathrm{X} 1+0.135 \mathrm{X} 2 \\
& +0.246 \mathrm{Y} 1+0.384 \mathrm{Y} 2
\end{aligned}
$$

The regression equation had a standardized coefficient value of 0.217 for service quality, 0.135 for product diversity, 0.384 for customer satisfaction, and 0.396 for WoM. Satisfaction had a more substantial influence on loyalty. It was because the customer felt happy to make a purchase, was satisfied to make a purchase, the product met expectations, the product did not disappoint, and the customer did not complain about the product. It indicated that customer expectations affected customer loyalty.

\subsection{Model Test}

In model I, the Adjusted R Square value was 0.502. It signified that the effect of service quality and product diversity on satisfaction was $50.2 \%$, or the variation of changes that occurred in satisfaction could be explained by $50.2 \%$ of service quality and product diversity, while $49.82 \%$ were influenced by other variables and were not examined. The calculated F-value was 50,948 with a significance level of $0.000<0.05$, meaning that the variable service quality and product diversity simultaneously affected the customer satisfaction variable. It indicated that the model that included the research variables above was correct (goodness of fit).

In model II, the Adjusted R Square value was 0.556. It denoted that the effect of service quality and product diversity on satisfaction was $55.6 \%$, or the variation of changes that occurred in WoM could be explained by $55.6 \%$ of service quality and product diversity, while $45.4 \%$ was influenced by other variables which were not examined. The calculated $F$ value was 62,947 with a significance level of $0.000<0.05$, indicating that the variable service quality and product diversity simultaneously influenced the customer satisfaction variable. It suggested that the model that included the research variables above was correct (goodness of fit).

In model III, the Adjusted R Square value was 0.714. It illustrated that the effect of service quality, product diversity, satisfaction, and WoM on loyalty was $71.4 \%$ or the variations in changes that occurred in loyalty could be explained by service quality, product diversity of satisfaction, and WoM by $71.4 \%$, while $28.9 \%$ was influenced by other variables researched. The calculated F-value was 62,839 with a significance level of $0.000<0.05$, indicating that the variable service quality, product diversity, satisfaction, and WoM simultaneously impacted the customer loyalty variable. It implied that the model that included the research variables above was correct (goodness of fit).

\subsection{Hypothesis Testing}

This test aimed to determine the effect of the independent variable on the dependent variable partially. This test was also carried out to determine whether the proposed hypothesis was accepted or rejected. The hypothesis is accepted if the $\beta$ value $>0$ and the $\mathrm{p}$-value $<0.05$ (Ghozali, 2016).

Based on Table 1, it can be seen that service quality had a positive effect with beta $=0.494$ and was significant on customer satisfaction $(\rho=0.000<0.05)$. Thus, hypothesis 1 was accepted.

Product diversity had a positive effect with beta $=0.326$ and was significant on customer satisfaction $(\rho=0.000$ $<0.05)$; thus, hypothesis 2 was accepted.

Service quality had a positive effect with beta $=0.601$ and was significant on customer WoM $(\rho=0.000<0.05)$; thus, hypothesis 3 was accepted.

Product diversity had a positive effect with beta $=0.608$ and was significant on customer WoM $(\rho=0.002<0.05)$; thus, hypothesis 4 was accepted.

Service quality had a positive effect with beta $=0.217$ and was significant on customer loyalty $(\rho=0.009<0.05)$; thus, hypothesis 5 was accepted.

Product diversity had a positive effect with beta $=0.135$ and was significant on customer loyalty $(\rho=0.048<0.05$ ); thus, hypothesis 6 was accepted.

WoM had a positive effect with beta $=0.246$ and was significant on customer loyalty $(\rho=0.008<0.05$ ); thus, hypothesis 7 was accepted.

Satisfaction had a positive effect with beta $=0.384$ and was significant on customer loyalty ( $\rho=0.000<0.05$ ); thus, hypothesis 8 was accepted.

\subsection{Mediation Test with Sobel Test}

To test the significant efficiency of the indirect (mediation) effect, a software developed by Sobel (1982) was utilized, which is better known as the Sobel test (Ghozali, 2016).

Satisfaction mediated the effect of service quality on loyalty with a $\mathrm{Z}$ value of 5.5499 and a significance level of $0.000<0.05$. The indirect effect was greater than the direct effect, so it could be said that satisfaction mediated the effect of service quality on loyalty.

Satisfaction mediated the effect of product diversity on loyalty with a $Z$ value of 5.4312 and a significance level of $0.000<0.05$. The indirect effect was greater than the direct 
effect, so it could be said that satisfaction mediated the effect of product diversity on loyalty.

WoM mediated the effect of service quality on loyalty with a $Z$ value of 5.1177 and a significance level of 0.000 $<0.05$. The indirect effect was greater than the direct effect, so it could be said that WoM mediated the effect of service quality on loyalty.

WoM mediated the effect of product diversity on loyalty with a $\mathrm{Z}$ value of 5.0227 and a significance level of 0.000 $<0.05$. The indirect effect was greater than the direct effect, so it could be said that WoM mediated the effect of product diversity on loyalty.

\section{Discussion}

Service quality had a positive and significant effect on customer satisfaction. The service quality applied by Batik Craftwork could give a good impression and was in accordance with the promise so that what the customer got was as desired, which resulted in customer satisfaction. It is in accordance with the opinion of Coker (2013), Giovanis, Zondiros and Tomaras (2014), Shi, Prentice and He (2014), and Suhaily and Soelasih (2017) that by increasing consumer satisfaction with service quality, customers will be able to improve their memory so that they are likely to refer to potential buyers.

Product diversity had a positive and significant effect on customer satisfaction. Various products derived from Batik Craftwork using natural dyes, unique products, and distinctive products with their techniques would increase customer satisfaction. In accordance with the opinion of Sari and Setiyowati (2017) and Suhaily \& Soelasih (2017), a variety of products according to customer desires increased customer satisfaction.

Service quality had a positive and significant effect on WoM. Batik Craftwork's service quality by always providing good batik trends and market information would be a positive experience, encouraging customers to share it in the form of positive information. This study's results support the findings of Saktiani (2015) and Liu \& Lee (2016), which revealed the influence of service quality on WoM. The better the service quality, the better and more pleasant will be the experience of the customer, and it would be responded to by telling positive things about the product to others both online and offline.

Product diversity had a positive and significant effect on WoM. Product diversity of Batik Craftwork communicated good messages through social networks through exhibitions, fashion shows, and social media in the form of reseller networks, Instagram, fan pages, Facebook, and websites. These results support the findings of Huda and Syahrul (2016), Adi et al. (2019), and Anggraeni et al. (2019), which explained the effect of product diversity on WoM

Service quality had a positive and significant effect on customer loyalty. High service quality would be a positive experience that encouraged consumers to have a positive attitude and behavior in the form of loyalty. This study's results also support the findings of Joshua and Haryadi (2013), Shi, Prentice and He (2014), Setyowati \& Wiyadi (2016), Agha Kasiri et al. (2017), and Setyowati \& Wiyadi (2016), which stated that service quality positively affected customer loyalty.

Product diversity had a positive and significant effect on customer loyalty. The various products produced by Batik Craftwork were batik with a compound pattern of batik motifs with natural dyes applied in fashion, bedding, home decor, accessories, and merchandising. The results of the production waste in the form of patchwork were processed into various accessories. These various products provided many choices to consumers so that they became increasingly loyal. This study results support the findings of Huda and Syahrul (2016), Adi et al. (2019), and Anggraeni et al. (2019) that product diversity had a positive effect on customer loyalty. Companies must increase their products and services' diversity to achieve customer satisfaction, and it can lead to loyalty.

WoM had a positive and significant effect on customer loyalty. WoM containing product reviews and purchases would positively affect purchases (Tsai et al., 2017). NextYoo, Sanders and Moon (2013) explained that eWoM affected customer loyalty in their online shopping patterns. It was also found that personal site identification had a more significant impact on electronic loyalty than social site identification. When WoM is positive, it will strengthen the consumer's positive experience of the product so that loyal attitudes and behaviors will emerge. This study's results support Liang and Scammon (2011) findings that WoM positively influenced customer loyalty. This study's results also support the findings of Dennis et al. (2009) that WoM affected customer loyalty.

Satisfaction had a positive and significant effect on customer loyalty. This study's results support the findings of Muafa et al. (2020), Kasiri et al. (2017), Susanti and Ekazaputri (2018), and Song, Wang, and Han (2019), which found that satisfaction positively impacted customer loyalty. The higher the consumer satisfaction, the more the product performance is considered better than expectations so that consumers talk about positive things about the product or service, are willing to provide recommendations to others, and are willing to make repeat purchases in the future.

\section{Conclusion}

Batik Craftwork, apart from being a place for education, creativity, and innovation in the field of batik, also produces innovative batik works for customers. Batik Craftwork also provides assistance activities to the community on creative techniques in batik, such as the tie-dyeing technique, shibori and smock techniques, the use of natural dyes, and the use of waste around the community. 
Service quality and product variety had a positive influence on customer satisfaction. The higher the service quality and product diversity, the more positive impact it would have on customer satisfaction level. It means that to build customer satisfaction, Batik Craftwork requires a high service quality.

Service quality and product variety had a positive influence on WoM. The higher the service quality and product varieties, the more positive its impact on the customer WoM level. To build a WoM for Batik Craftwork customers, high product diversity is required.

Service quality, product diversity, customer satisfaction, and WoM positively influenced loyalty. The higher the service quality, product diversity, customer satisfaction, and WoM, the more positive impact on the customer loyalty level. To build customer loyalty, Batik Craftwork needs high satisfaction.

Service quality was more effective in having an indirect effect through satisfaction than directly on loyalty, and product diversity more effectively affected indirectly through satisfaction rather than directly on loyalty. Besides, service quality had a more effective indirect effect through WoM than directly on loyalty, and product diversity was more effective in indirectly affecting WoM than directly on loyalty.

\section{References}

Adi, P. H., Dhiaulhaq, M. I., \& Novandari, W. (2019). Customer Satisfaction As The Moderating Variable of Customer Loyalty. Journal of Accounting, Management and Economics, 21(1), 13-22. [Indonesian].

Alam, N., \& Al-Amri, H. A. (2020). Service Quality Perception and Customer Satisfaction in Islamic Banks of Oman. Journal of Asian Finance, Economics and Business, 7(9), 499-504. https:// doi.org/10.13106/jafeb.2020.vol7.no9.499

Alrwashdeh, M., Jahmani, A., Ibrahim, B., \& Aljuhmani, H. Y. (2020). Data to model the effects of perceived telecommunication service quality and value on the degree of user satisfaction and e-WOM among telecommunications users in North Cyprus. Data in Brief, 28, 104981. https://doi. org/10.1016/j.dib.2019.104981

Anggraeni, Y., Retnoningsih, D., \& Muhaimin, A. (2019). The Influence of Satisfaction on Consumer Loyalty of Sumawe Coffee Malang. Agricultural Socio-Economics Journal, 19(1), 19-25.

Bhattacharya, C. B., \& Sen, S. (2003). Consumer-company identification: A framework for understanding consumers' relationships with companies. Journal of Marketing, 67(2), 76-88. https://doi.org/10.1509/jmkg.67.2.76.18609

Brown, T. J., Barry, T. E., Dacin, P. A., \& Gunst, R. F. (2005), Spreading the word: Investigating antecedents of consumers' positive word-of-mouth intentions and behaviors in a retailing context. Journal of the Academy of Marketing Science, 33(2), 123-138. https://doi.org/10.1177/0092070304268417

Cengiz, E., \& Yayla, H. E. (2007). The effect of marketing mix on positive word of mouth communication: Evidence from accounting offices in Turkey. Innovative Marketing, 3(4), $73-86$.

Chang, S. C., Tein, S. W., \& Lee, H. M. (2010). Social capital, creativity, and new product advantage: An empirical study. International Journal of Electronic Business Management, $8(1), 43-45$.

Coker, B. (2013). Antecedents to website satisfaction, loyalty, and word-of-mouth. JISTEM-Journal of Information Systems and Technology Management, 10(2), 209-218.

Giovanis, A. N., Zondiros, D., \& Tomaras, P. (2014). The Antecedents of Customer Loyalty for Broadband Services: The Role of Service Quality, Emotional Satisfaction and Corporate Image. Procedia - Social and Behavioral Sciences, 148, 236-244. https://doi.org/10.1016/j.sbspro.2014.07.039

Ghozali, I. (2016). Multivariate Analysis Application with SPSS 19. Semarang, Indonesia: BP Universitas Diponegoro. [Indonesian].

Griffin, J. (2013). Customer loyalty. Jakarta: Erlangga Press. [Indonesian].

Hermawan, B., Basalamah, S., Djameren, A., \& Plyriadi, A. (2017). Effect of Service Quality and Price Perception on Corporate Image, Customer Satisfaction and Customer Loyalty among Mobile Telecommunication Services Provider. IRAInternational Journal of Management \& Social Sciences, 8(1), $62-73$.

Huda, S., \& Syahrul, M. F. (2016). The Effect of Product Differentiation on the Creation of Word of Mouth in Unico Mart Customers, Performance. Journal of Management and Business Start-Up Bisnis, 1(4). [Indonesian].

Jahanshahi, A. A., Gashti, M. A. H., Mirdamadi, S. A., Nawaser, K., \& Khaksar, S. M. S. (2011). Study Effects of Customer Service and Product Quality on Customer Satisfaction and Loyalty. International Journal of Humanities and Social Science, 1(7), 253-260.

Joshua, T., \& Haryadi, E. (2013). Analysis Pengaruh Brand Image, Price Perception and Service Quality on Customer Loyalty to Urban Kitchen Customers. Management Journal, 1(1), 13-27. [Indonesian].

Kasiri, L. A., Cheng, K. T. G., Sambasivan, M., \& Sidin, S. M. (2017). Integration of standardization and customization: Impact on service quality, customer satisfaction, and loyalty. Journal of Retailing and Consumer Services, 35, 91-97.

Kotler, P., \& Keller, K. L. (2012). Marketing Management (14th ed.). New Jersey: Prentice Hall International.

Lee, H. J., \& Seong, M. H. (2020). A Study on the Effects of Business Service Quality on Satisfaction, Commitment, Performance, and Loyalty at a Private University. Journal of Asian Finance, Economics and Business, 7(9), 439-453. https:// doi.org/10.13106/jafeb.2020.vol7.no9.439 
Endang TJAHJANINGSIH, Dewi Handayani Untari NINGSIH, Agus Prasetyo UTOMO /

Journal of Asian Finance, Economics and Business Vol 7 No 12 (2020) 481-490

Li, F., \& Du, T. C. (2017). The effectiveness of word of mouth in offline and online social networks. Expert Systems with Applications, 88, 338-351. https://doi.org/10.1016/j. eswa.2017.07.004

Liang, B., \& Scammon, D. L. (2011). E-Word-Of-Mouth on Health Social Networking Sites: An Opportunity For Tailored Health Communication, Journal of Consumer Behaviour, 10(6).

Libai, B., Bolton, R., Bügel, M., de Ruyter, K., Götz, O., \& Risselada, H. (2010). Customer-To-Customer Interactions: Broadening The Scope Of Word Of Mouth Research. Journal of Service Research, 13(3), 267-282

Liu, C. H. S., \& Lee, T. (2016). Service Quality and Price Perception of Service: Influence on Word-of-Mouth and Revisit Intention. Journal of Air Transport Management, 52, 42-54.

Lombart, C., \& Louis, D. (2012). Consumer Satisfaction and Loyalty: Two Main Consequences of Retailer Personality. Journal of Retailing and Consumer Services, 19(6), 644-652. https://doi.org/10.1016/j.jretconser.2012.08.007

Muafa, I. W., Awal, M., Wahyudhi, C. A., Waas, S., \& Noer, E. (2020, March). The effect of product quality and service quality on customer satisfaction in crocodile skin crafts industry. In IOP Conference Series: Earth and Environmental Science, 427(1), 012028.

Nguyen, D. T., Pham, V. T., Tran, D. M., \& Pham, D. B. T. (2020). Impact of Service Quality, Customer Satisfaction and Switching Costs on Customer Loyalty. Journal of Asian Finance, Economics and Business, 7(8), 395-405. https://doi. org/10.13106/jafeb.2020.vol7.no8.395

Nurhasanah, N. (2010). Analysis of the Effect of Product Diversity, Service Quality and Customer Satisfaction on Customer Loyalty at PT. Hero Supermarket. Faculty of Economics and Business, Syarif Hidayatullah State Islamic University Jakarta. [Indonesian].

Nuraini, A. (2014). The Influence of Image, Services, Service Accessories, Product Diversity and Customer Value on Customer Loyalty (Studies on Customers of BPD DIY Syariah Yogyakarta). Jurnal Ekonomi dan Bisnis Islam, IX(1). [Indonesian]

Parasuraman, A., Zeithaml, V. A., \& Berry, L. L. (1985). A Conceptual Model of Service Quality and Its Implications for Future Research. Journal of Marketing, 49(4), 41-50. https:// doi.org/10.1177/002224298504900403

Parasuraman, A., Zeithaml, V. A., \& Berry, L. L. (1988). SERVQUAL: A Multiple-Item Scale for Measuring Consumer Perceptions of Service Quality. Journal of Retailing, 64(1), 12-40.

Pauwels, K., Aksehirli, Z., \& Lackman, A. (2016). Like the ad or the brand? Marketing Stimulates different electronic word-of-mouth content to drive online and offline performance. International Journal of Research in Marketing, 33, 639-655.

Powers, T. L., Jack, E. P., \& Choi, S. (2018). Price and Quality Value Influences on Discount Retail Customer Satisfaction and
Loyalty. Journal of Consumer Satisfaction, Dissatisfaction and Complaining Behaviour, 31, 1-19.

Prasetyo, E. (2007). The Effect of Product and Service Diversity on Consumer Loyalty at Assgros Sartika Gemolong Supermarkets in Sragen Regency. Semarang State University, Semarang. [Indonesian]

Ranjbarian, B., Sanayei, A., Kaboli, M. R., \& Hadadian, A. (2012). An Analysis of Brand Image, Perceived Quality, Customer Satisfaction and Repurchase Intention in Iranian Department Stores. International Journal of Business and Management, $7(6), 40-48$.

Razak, I., Nirwanto, N., \& Triatmanto, B. (2016). The Impact of Product Quality and Price on Consumer Satisfaction with the Mediator of Customer Value. Journal of Marketing and Management Research, 30, 59-68.

Rokonuzzaman, M. D., Harun, A., Al-Emran, M. D., Victor, R., \& Prybutok, V. (2020). An Investigation into The Link Between Consumer's Product Involvement and Store Loyalty: The Roles of Shopping Value Goals and Information Search As The Mediating Factors. Journal of Retailing and Consumer Services, 52. https://doi.org/10.1016/j.jretconser.2019.101933

Sari, N., \& Setiyowati, S. (2017). The Influence of Product Diversity and Service Quality on Consumer Satisfaction in $P B$ Swalayan Metro. Darmajaya Institute of Informatics and Business. Bandar Lampung. [Indonesian].

Setyowati, E., \& Wiyadi, W. (2016). The Influence of Service Quality, Price, and Brand Image on Customer Loyalty with Customer Satisfaction as a Mediating Variable. Competitiveness Journal of Resource Management Economics, 18(2), 102-112.

Shi, Y., Prentice, C., \& He, W. (2014). Linking Service Quality, Customer Satisfaction and Loyalty in Casinos, Does Membership Matter? International Journal of Hospitality Management, 40(7), 81-91. https://doi.org/10.1016/j. ijhm.2014.03.013

Sobel, M. E. (1982). Asymptotic Confidence Intervals for Indirect Effect in Structural Equation Models. In: S. Leinhardt (Ed.), Sociological Methodology 1982 (pp. 290-312). Washington, DC: American Sociological Association.

Solimun, S., \& Fernandes, A. A. R. (2018). The Mediation Effect of Customer Satisfaction in the Relationship between Service Quality, Service Orientation, and Marketing Mix Strategy to Customer Loyalty. Journal of Management Development, 37(1), 76-87. https://doi.org/10.1108/JMD-12-2016-0315

Song, H. J., Wang, J. H., \& Han, H. (2019). Effect of Image, Satisfaction, Trust, Love, and Respect on Loyalty Formation for Name-Brand Coffee Shops. International Journal of Hospitality Management, 79(5), 50-59. https://doi. org/10.1016/j.ijhm.2018.12.011

Sugiyono. (2016). Qualitative and Quantitative Research Methods $R \& D$. Bandung: Alfabeta Press. [Indonesian].

Suhaily, L., \& Soelasih, Y. (2017). What Effects Repurchase Intention of Online Shopping. International Business Research, 10(12), 113-122. 
Susanti, F., \& Ekazaputri, W. (2018). Service Performance and Satisfaction as Moderating Variables to Customer Loyalty at PT BPR Labuh Gunung Payakumbuh. Jurnal Benefita, 3(3), 433-333.

Tang, C., Tang, Y., \& Su, S. (2019). R\&D Internationalization, Product Diversification and International Performance for Emerging Market Enterprises: An Empirical Study on Chinese Enterprises. European Management Journal, 37, 529-539

Tjahjaningsih, E., Handayani, D., Utomo, A. P., \& Rozak, H. A. (2016). Development and Empowerment of Semarang Batik Craftsmen Based on Assistance Strategy of Fractal Batik in Then Effort to Build Sustainable Competitive Advantage. International Journal of Applied Business and Economic Research, 14(13), 8853-8866.

Tjahjaningsih, E., Handayani, D., Utomo, A. P., \& Rozak, H. A. (2017). Creative Technique Strategy Based on the Technique of Tie Dye and Smock Using Natural Colouring to Improve the Performance of the Craftsmen of Written Batik in Semarang. International Journal of Economic Research, 14(12), 91-103.

Tjahjaningsih, E., Handayani, D., Utomo, A. P., \& Santosa, A. B. (2020). Creative Techniques of Contemporary Batik Motifs Based on History. International Journal of Organizational Innovation, 12(3).
Tsai, C. H., Chiung, C., \& Tan, M. J. E. (2017). The Cause and Effects of Word of Mouth from Consumer Intention and Behavior Perspective: A SEM Model Approach. Journal of Economic and Social Thought, 4(2), 212-231.

Tran, V. D., \& Le, N. M. T. (2020). Impact of Service Quality and Perceived Value on Customer Satisfaction and Behavioral Intentions: Evidence from Convenience Stores in Vietnam. Journal of Asian Finance, Economics and Business, 7(9), 517-526. https://doi.org/10.13106/ jafeb.2020.vol7.no9.517

Utama, M. B., \& Ngatno, N. (2017). The Effect of Product Diversity and Service Quality on Repurchase Decisions through Customer Satisfaction as an Intervening Variable (Study on Gelael Mall Ciputra Semarang Consumers). Journal of Business Administration Science, 6(3). [Indonesian]

Walter, N., Cleff, T., \& Chu, G., (2013). Brand Experience's influence On Customer Satisfaction and Loyalty: A Mirage in Marketing Research. International Journal Management Research and Business Strategy, 2(1), 130-144.

Wilujeng, S., \& Mudzakkir, M. F. (2015). The Influence of Product Diversity on Customer Satisfaction at Indomaret Modern Stores, Sukun District, Malang City. Universitas Kanjuruan Malang, Indonesia. [Indonesian]. 